\title{
Use of hyperbaric oxygen therapy in the treatment of osteoradionecrosis of the maxilla in patients with head and neck cancer
}

\author{
Uso da oxigenoterapia hiperbárica no tratamento da osteorradionecrose dos maxilares em \\ pacientes com câncer de cabeça e pescoço \\ Uso de la oxigenoterapia hiperbárica en el tratamiento de la osteorradionecrosis de los maxilares en \\ pacientes con cáncer de cabeza y cuello
}

Received: 01/14/2022 | Reviewed: 01/18/2022 | Accept: 01/21/2022 | Published: 01/23/2022

Lucas Andeilson dos Santos Matos

ORCID: https://orcid.org/0000-0001-6258-7327 Centro Universitário Fametro, Brazil

E-mail: lucasmmatos@outlook.com

Mauro Wilker Cruz de Azevedo

ORCID: https://orcid.org/0000-0002-6668-0665 Centro Universitário Fametro, Brazil

E-mail: maurowil.azevedo@gmail.com

Rafaela Alves Castro

ORCID: https://orcid.org/0000-0003-0892-4606 Centro Universitário Fametro, Brazil

E-mail: rafaelacastro.odonto@gmail.com

Carla Natiara Rabelo Mesquita

ORCID: https://orcid.org/0000-0002-6564-980X Centro Universitário Fametro, Brazil

E-mail: natiararabelo.odonto@outlook.com

Antonio Ítalo de Souza Sampaio ORCID: https://orcid.org/0000-0001-7739-7761 Centro Universitário Fametro, Brazil E-mail: italosampaio238@gmail.com

Samara Lima Rabelo

ORCID: https://orcid.org/0000-0002-3144-8030 Centro Universitário Fametro, Brazil E-mail: samara rabelo@live.com

Lauana Kelly Cavalcante Mendes ORCID: https://orcid.org/0000-0003-1018-3157 Centro Universitário Fametro, Brazil E-mail: lauanakelly024@gmail.com

Maria Karolina de Freitas Queiroz ORCID: https://orcid.org/0000-0001-5905-4466 Centro Universitário Fametro, Brazil

E-mail: queiroz.karolina@yahoo.com.br

Jonatan Costa Gomes

ORCID: https://orcid.org/0000-0002-6741-1045

Universidade Federal de Mato Grosso, Brasil E-mail: jonatanfaen@yahoo.com.br

\begin{abstract}
This study aimed to understand how hyperbaric oxygen therapy can act in the treatment of osteoradionecrosis of the jaws in patients with head and neck cancer. A total of 266 publications were found. After applying the inclusion and exclusion criteria, 19 articles were selected. Osteoradionecrosis is a condition with great potential for bone destruction, and therefore, many methods for treatment have been vehemently studied. Although the mechanism of action of hyperbaric oxygen therapy is not fully understood, it is known that the physiochemistry that drives the action is a result of two factors: $100 \%$ inspired oxygen and exposure to high atmospheric pressure. In addition, oxygen when present in larger quantities in the body can act to heal necrotic regions, oxygenating regions where hypoxia and hypoperfusion have occurred. However, this therapy is not totally innocuous and has significant issues for the patient, among them, the limitation of its access, and with this, the cost for oxygen therapy is very high. The negative impact that osteoradionecrosis has on oncology patients can be seen, and how hyperbaric therapy can act in the treatment of necrosis caused by oncotherapy in patients with head and neck cancer, due to its numerous effects on oxidative
\end{abstract}


metabolism. In contrast, it is necessary to correctly evaluate the indication of the treatment, because the therapy has relevant adverse effects that deserve attention.

Keywords: Hyperbaric oxygenation; Osteoradionecrosis; Radiotherapy.

\section{Resumo}

Este estudo teve como objetivo entender como a oxigenoterapia hiperbárica pode atuar no tratamento da osteorradionecrose dos maxilares em pacientes com câncer de cabeça e pescoço. Foram encontradas um total de 266 publicações. Após a aplicação dos critérios de inclusão e exclusão, 19 artigos foram selecionados. A osteorradionecrose é uma condição com grande potencial de destruição óssea e, portanto, muitos métodos de tratamento têm sido veementemente estudados. Embora o mecanismo de ação da oxigenoterapia hiperbárica não seja totalmente compreendido, sabe-se que a físico-química que impulsiona a ação é o resultado de dois fatores: oxigênio $100 \%$ inspirado e exposição a alta pressão atmosférica. Além disso, o oxigênio quando presente em maiores quantidades no corpo pode atuar para curar regiões necróticas, regiões oxigenadoras onde ocorreram hipóxia e hipoperfusão. Entretanto, esta terapia não é totalmente inócua e tem problemas significativos para o paciente, entre eles, a limitação de seu acesso, e com isto, o custo da oxigenoterapia é muito alto. O impacto negativo que a osteorradionecrose tem sobre os pacientes oncológicos pode ser visto, e como a terapia hiperbárica pode atuar no tratamento da necrose causada pela oncoterapia em pacientes com câncer de cabeça e pescoço, devido a seus numerosos efeitos sobre o metabolismo oxidativo. Em contraste, é necessário avaliar corretamente a indicação do tratamento, pois a terapia tem efeitos adversos relevantes que merecem atenção.

Palavras-chave: Oxigenoterapia hiperbárica; Osteorradionecrose; Radioterapia.

\section{Resumen}

Este estudio pretendía comprender cómo puede actuar la oxigenoterapia hiperbárica en el tratamiento de la osteorradionecrosis de los maxilares en pacientes con cáncer de cabeza y cuello. Se encontraron un total de 266 publicaciones. Tras aplicar los criterios de inclusión y exclusión, se seleccionaron 19 artículos. La osteorradionecrosis es una afección con gran potencial de destrucción ósea y, por tanto, se han estudiado con vehemencia muchos métodos de tratamiento. Aunque el mecanismo de acción de la oxigenoterapia hiperbárica no se conoce del todo, se sabe que la fisicoquímica que impulsa la acción es el resultado de dos factores: el 100\% de oxígeno inspirado y la exposición a una alta presión atmosférica. Además, el oxígeno, cuando está presente en mayores cantidades en el cuerpo, puede actuar para curar las regiones necróticas, oxigenando las regiones donde se há producido hipoxia e hipoperfusión. Sin embargo, esta terapia no es totalmente inocua y tiene importantes problemas para el paciente, entre ellos, la limitación de su acceso, y con ello, el coste de la oxigenoterapia es muy elevado. Se puede ver el impacto negativo que tiene la osteorradionecrosis en los pacientes con cáncer, y cómo la terapia hiperbárica puede actuar en el tratamiento de la necrosis causada por la oncoterapia en pacientes con cáncer de cabeza y cuello, debido a sus numerosos efectos sobre el metabolismo oxidativo. En cambio, es necesario valorar correctamente la indicación del tratamiento, ya que la terapia tiene efectos adversos relevantes que merecen atención.

Palabras clave: Oxigenoterapia hiperbárica; Osteorradionecrosis; Radioterapia.

\section{Introduction}

The damage caused by oncotherapy in the head and neck region has a decisive impact on the quality of life of patients, where the effects generated have a direct impact on the stomatognathic system. Among the treatment modalities, radiotherapy is one of the most common and aims to destroy and prevent the development of tumor cells, using ionizing rays (Shaw et al., 2018).

Although cancer treatment is effective, high doses of radiation therapy can induce many side effects, such as osteoradionecrosis, a serious and debilitating complication caused by radiation therapy after treatment of head and neck cancer (Gavriel et al., 2017).

The pathogenesis of this condition is the result of fibrosis of the blood vessels in the irradiated area, which makes the tissue hypovascular, hypocellular and hypoxic, so that bone sequestration occurs and there may be exposure through the overlying skin or mucosa, persisting as a non-healing wound for 3 months or more. Risk factors that may predispose to necrosis include the patient's age, location of the primary tumor, type of treatment, frequency and dose of radiation (Gupta et al., 2013).

The treatment of osteoradionecrosis is aimed at eliminating pain, controlling infection and reducing dissemination, and will be determined by the degree of necrosis present, requiring conservative interventions, such as debridement to remove 
all necrotic tissue, in addition to the use of antimicrobial solutions and antibiotic therapy to prevent secondary infections. In addition, in more complex cases, in which conservative treatment no longer shows expressive results, surgical approaches are required, such as total or partial resection and reconstruction with bone graft (Shaw et al., 2018).

Therefore, interventions are required for the correct management and treatment of bone necrosis. In recent years, the proposed treatment of osteoradionecrosis has a greater focus on the process of revascularization of irradiated tissues and improvement of the compromised microcirculatory condition, so that, based on the current concepts of the pathophysiology of necrosis, hyperbaric oxygen therapy has grown its scope of action in dentistry within the field of oncology, being used due to its relevant therapeutic effects (André-Lévigne et al., 2016).

The introduction of pure oxygen at an elevated ambient pressure is called hyperbaric oxygenation, this therapy provides a transient elevated partial pressure of oxygen within the tissue. The first observation of the beneficial effects of hyperbaric oxygenation on bone regeneration was made in 1966, when it was found that increased oxygen levels can promote tissue vascularization (Grassmann et al., 2015).

Based on the above, this study aimed to understand how hyperbaric oxygen therapy can act in the treatment of osteoradionecrosis of the jaws in patients with head and neck cancer.

\section{Methodology}

The study is an integrative literature review, structured in a protocol of six differentiated stages, previously established, with the objective of maintaining scientific and methodological rigor: 1) identification of the study topic and elaboration of the guiding question; 2) literature search and establishment of the inclusion and exclusion criteria; 3) definition of the information to be extracted from the selected studies and characterization; 4) critical analysis of the included studies; 5) interpretation and discussion of the results; 6) presentation of the review/synthesis of knowledge; 7) analysis of the results of the studies; 8) analysis of the results of the studies; and 9) analysis of the results of the studies (Souza et al., 2010).

The guiding research question was elaborated based on the strategy Population, Interest and Context (PICo) (Lockwood et al., 2017), for which the following were considered: P - patients with head and neck cancer; I - hyperbaric oxygen therapy; Co - treat osteoradionecrosis of the jaw. Thus, the following question was asked: "Can hyperbaric oxygen therapy treat osteoradionecrosis of the jaws in patients with head and neck cancer?".

The bibliographic survey was conducted in November 2021, through virtual access to the following databases Medical Literature Analysis and Retrival System Online (MEDLINE) by means of PubMed, Web of Science y EBSCOhost. In addition, a manual search was performed by reading the references of the selected included primary studies. In order to broaden the research results, all scientific articles were accessed through the Comunidade Acadêmica Federativa (CAFe), via the journals portal of the Coordenação de Aperfeiçoamento de Pessoal de Nível Superior (CAPES).

The databases were accessed by two independent researchers, who determined the sequence of use of descriptors and cross-references in each database and then correlated the results obtained, using the Rayyan Qatar Computing Research Institute (Rayyan QCRI) online platform, where duplicate exclusion and evaluation of titles and abstracts were performed blindly and concurrently. Divergent studies were reviewed by a third researcher (Ouzzani et al., 2016).

The search was conducted using controlled descriptors and their synonyms, in English, present in Medical Subject Headings (MeSH), by cross-referencing the descriptors, associated with Boolean operators OR \& AND, The search strategy was conducted in order to contemplate the peculiarities of each base (Figure 1). 
Figure 1 - Controlled and uncontrolled descriptors employed in the search strategy for population, interest, and context.

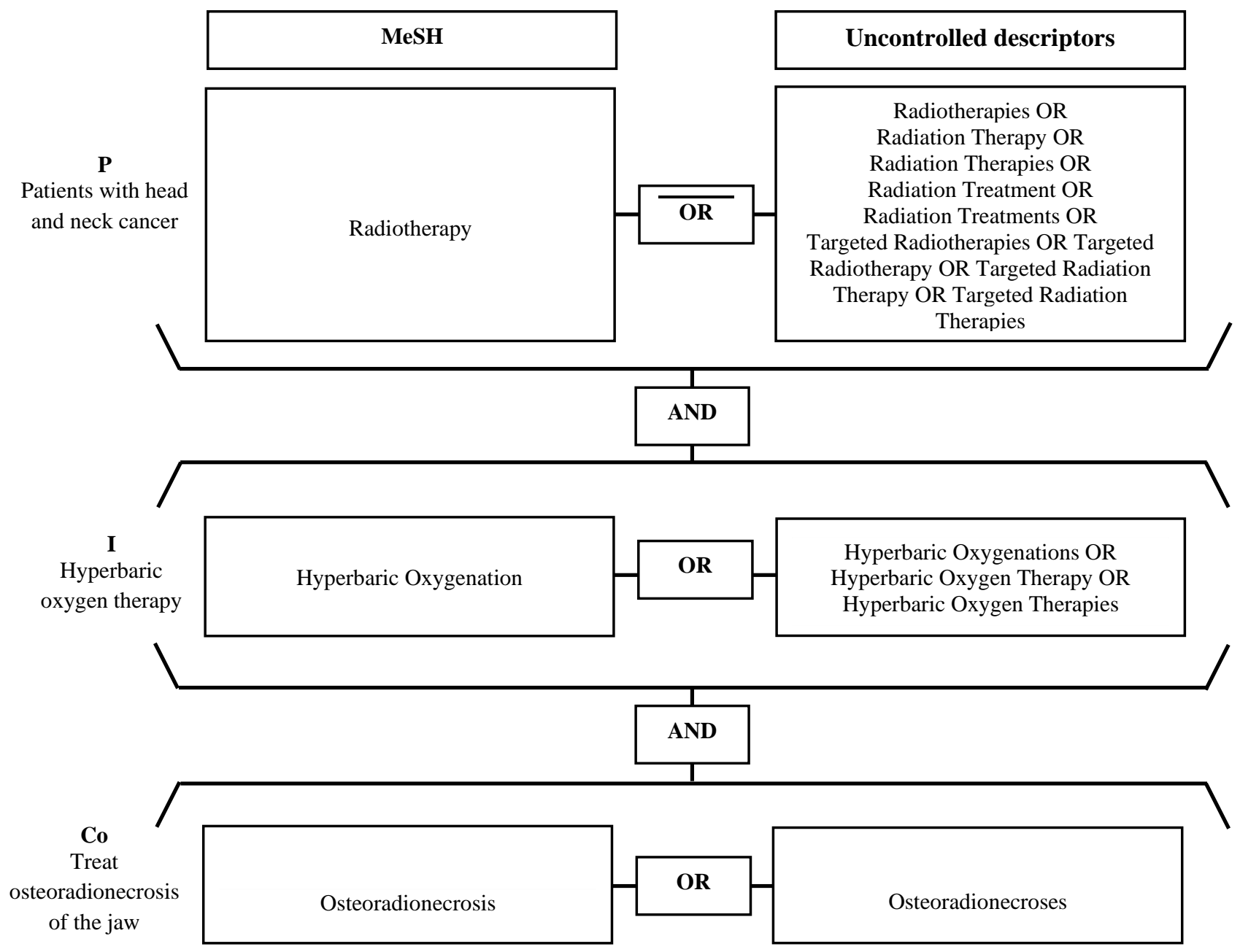

Source: Authors (2021).

Inclusion criteria were: primary articles that addressed the use of hyperbaric oxygen therapy as a treatment for osteoradionecrosis, published in the period 2010 to 2020, in English, with the full text available electronically in the database. The exclusion criteria were: review articles, editorials, congress proceedings, theses, dissertations, monographs, gray literature and articles that were not related to the guiding question established for the study.

In addition, to establish the level of scientific evidence, the following were considered: level 1 - meta-analysis and randomized controlled study; level 2 - experimental study; level 3 - quasi-experimental study; level 4 - descriptive, nonexperimental or qualitative study; level 5 - case or experience report; level 6 - consensus and expert opinion (Melnyk e Fineout-overholt, 2005).

It is worth mentioning that the selection and eligibility process of the articles was followed according to the instructions of the Preferred Reporting Items for Systematic Reviews and Meta-Analyses (PRISMA) (Page et al., 2021), as described in Figure 2. 
Figure 2 - Flowchart of the search and selection of articles found in the databases, according to the PRISMA recommendations.

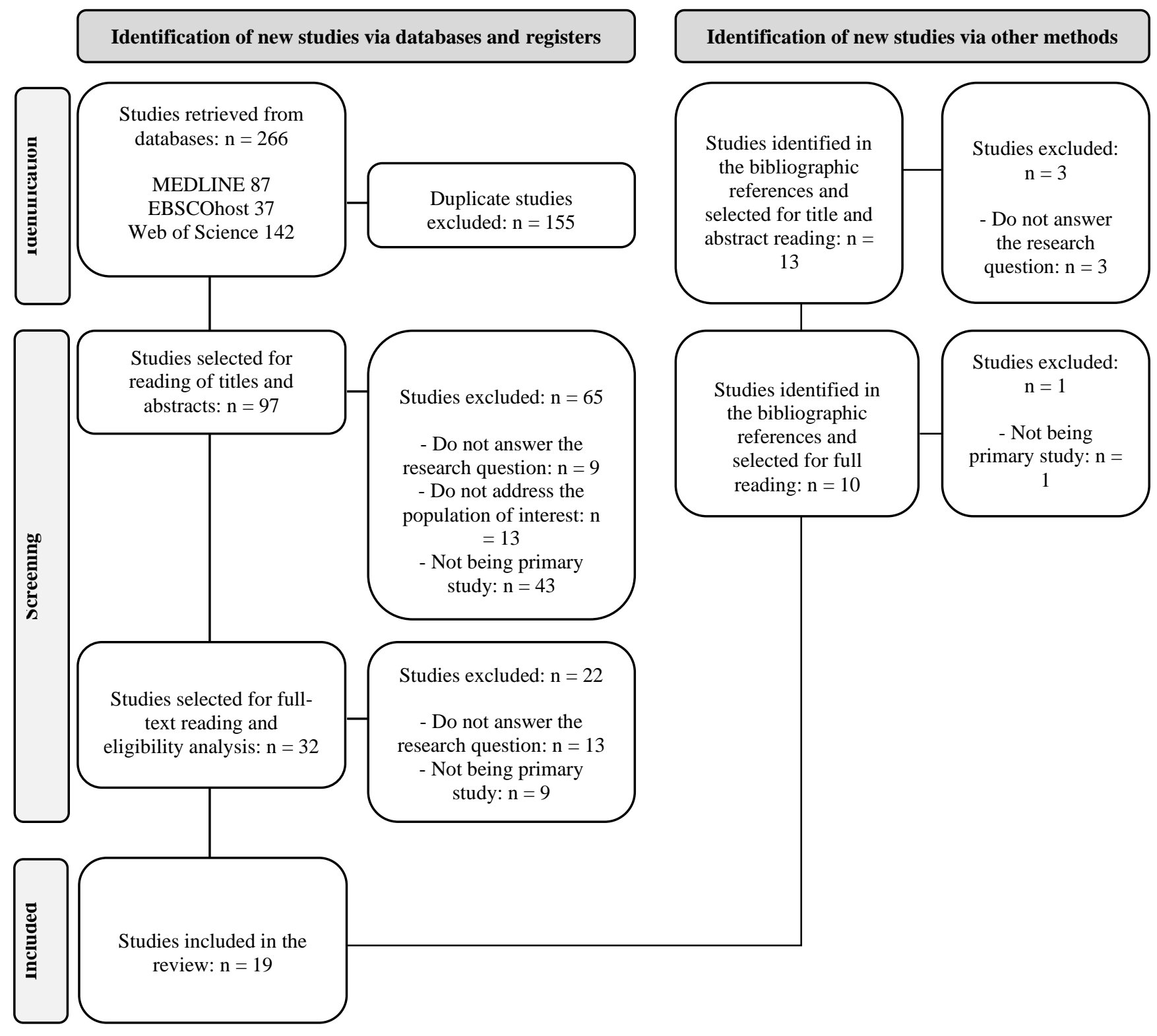

Source: Page et al. (2021).

\section{Results}

After bibliographic searches, a total of 266 publications were identified, of which, after applying the inclusion and exclusion criteria, 19 articles were selected to compose this review, distributed as follows: four (21,05\%) at MEDLINE/PubMed, three (15,79\%) at Web of Science, three (15,79\%) at EBSCOhost, and nine (47,37\%) by manual search.

Regarding study design, two (10,53\%) were randomized clinical trials, two $(10,53 \%)$ in vivo studies, three $(15,79 \%)$ in vitro studies, two $(10,53 \%)$ clinical trials, seven $(36,84 \%)$ retrospective studies, one $(5,26 \%)$ experimental study, and one $(5,26 \%)$ clinical case report, published between 2010 and 2020, with the highest concentration of studies in the year 2015 $(26,32 \%)$.

Table 1 presents the 19 selected publications according to the main author, year of publication, methodological aspects, objective, and outcome of the studies. 
Table 1 - Description of the studies found in the databases.

\begin{tabular}{|c|c|c|c|}
\hline $\begin{array}{l}\text { LEAD AUTHOR / } \\
\text { YEAR }\end{array}$ & $\begin{array}{c}\text { STUDY } \\
\text { METHODOLOGY }\end{array}$ & OBJECTIVE & MAIN RESULTS \\
\hline Baiula, 2020 & In vitro study & $\begin{array}{l}\text { To evaluate the role of integrin-mediated adhesion by } \\
\text { characterizing integrin receptor expression on } \\
\text { neutrophils during hyperbaric therapy and analyzing the } \\
\text { effect of a peptidomimetic } \alpha 4 \beta 1 \text { integrin antagonist } \\
\text { under these conditions. }\end{array}$ & $\begin{array}{l}\text { Oxygen therapy promotes wound healing and a } \\
\text { reduction of inflammatory cytokines in patients } \\
\text { with chronic non-healing wounds. The cell } \\
\text { adhesion function of both neutrophil integrins } \alpha 4 \text {, } \\
\beta 1 \text { and } \beta 2 \text { is significantly reduced, as is the } \\
\text { expression of } \beta 2 \text { integrins. }\end{array}$ \\
\hline Generaal, 2020 & Retrospective study & $\begin{array}{l}\text { Obtain information on the use and outcomes of } \\
\text { hyperbaric oxygen therapy for radiation-induced } \\
\text { complications after sarcoma treatment. }\end{array}$ & $\begin{array}{l}\text { Hyperbaric oxygen therapy is safe and beneficial } \\
\text { for the treatment of chronic wounds and late } \\
\text { radiation tissue damage in the sarcoma population. }\end{array}$ \\
\hline Sandhu, 2020 & Retrospective study & $\begin{array}{l}\text { To investigate the frequency of drug-related } \\
\text { osteoradionecrosis of the jaw after tooth extraction with } \\
\text { the use of post-extraction antibiotic coverage without } \\
\text { prophylactic hyperbaric oxygen in patients receiving } \\
\text { head and neck radiotherapy or antiresorptive drugs and } \\
\text { to determine possible associated factors. }\end{array}$ & $\begin{array}{l}\text { In our cohort of patients, the rate of post-extraction } \\
\text { osteoradionecrosis was lower and comparable to } \\
\text { rates reported in the literature. Larger prospective } \\
\text { studies are needed to validate the efficacy of post- } \\
\text { extraction antibiotics in reducing mandibular } \\
\text { osteoradionecrosis. }\end{array}$ \\
\hline Bosco, 2018 & Clinical Study & $\begin{array}{l}\text { To investigate the effect of hyperbaric oxygen therapy } \\
\text { on the production of reactive oxygen species in patients } \\
\text { with avascular necrosis of the femoral head and its } \\
\text { change in the levels of inflammatory cytokines. }\end{array}$ & $\begin{array}{l}\text { Hyperbaric oxygen therapy results in anti } \\
\text { inflammatory action in patients with avascular } \\
\text { necrosis of the femoral head. In addition, the } \\
\text { decrease in inflammatory markers reflected } \\
\text { reductions in edema visible on radiographic } \\
\text { images and reductions in the patient's pain. }\end{array}$ \\
\hline Rendina, 2018 & Clinical case report & $\begin{array}{l}\text { To present a case in which hyperbaric oxygen therapy } \\
\text { was used in conjunction with antibiotics for a } \\
\text { mandibular fracture that did not heal and was highly } \\
\text { suspected of osteomyelitis. }\end{array}$ & $\begin{array}{l}\text { The patient responded well and had healed } \\
\text { intraoral wounds and an objective decrease in } \\
\text { erythrocyte sedimentation rate throughout the } \\
\text { treatment. }\end{array}$ \\
\hline Dieleman, 2018 & Retrospective study & $\begin{array}{l}\text { To evaluate the success of hyperbaric oxygen therapy } \\
\text { (HBO) and surgery in the treatment of mandibular } \\
\text { osteoradionecrosis (ORN) in relation to the extent of the } \\
\text { ORN. }\end{array}$ & $\begin{array}{l}\text { Hyperbaric oxygen therapy can be recommended } \\
\text { for stage I and II mandibular osteoradionecrosis, } \\
\text { and for selected cases of stage III ORN, such as in } \\
\text { patients who have poor surrounding soft tissue } \\
\text { condition. }\end{array}$ \\
\hline Gavriel, 2017 & Retrospective study & $\begin{array}{l}\text { To report our results from data collected from patients } \\
\text { in a large single center trial using oxygen therapy to } \\
\text { treat osteoradionecrosis of the maxillary bone. }\end{array}$ & $\begin{array}{l}\text { There are controversies regarding the management } \\
\text { of osteoradionecrosis of the maxillofacial skeleton. } \\
\text { Our large single center experience supports the } \\
\text { efficacy of hyperbaric oxygen therapy for } \\
\text { osteoradionecrosis of the maxillary bone. }\end{array}$ \\
\hline Vezzani, 2017 & In vitro study & $\begin{array}{l}\text { Question whether hyperbaric oxygen therapy can exert } \\
\text { pro-angiogenic effects through modulation of } \\
\text { endothelial progenitor cells. }\end{array}$ & $\begin{array}{l}\text { Hyperbaric oxygen therapy may induce } \\
\text { modulation of endothelial progenitor cell biology } \\
\text { and this mechanism may activate the clinical } \\
\text { benefits exerted by neoangiogenesis and } \\
\text { neovascularization. }\end{array}$ \\
\hline $\begin{array}{l}\text { André-Lévigne, } \\
\qquad 2016\end{array}$ & In vivo study & $\begin{array}{l}\text { Elucidate whether hyperbaric oxygen therapy } \\
\text { accelerates wound closure and whether it counteracts } \\
\text { the negative effects of hyperglycemia and ischemia on } \\
\text { wound contraction. }\end{array}$ & $\begin{array}{l}\text { Wounds in which ischemia and hyperglycemia are } \\
\text { combined, as is often the case in diabetic patients, } \\
\text { have the best chance of benefiting from oxygen } \\
\text { therapy by increasing fibroblast recruitment and } \\
\text { higher cell counts in the granulation tissue. }\end{array}$ \\
\hline Sureda, 2016 & Clinical Study & $\begin{array}{l}\text { Define the time course of various changes in the } \\
\text { response of hyperbaric oxygen therapy in patients with } \\
\text { chronic wounds in whom conventional treatments have } \\
\text { proven ineffective. }\end{array}$ & $\begin{array}{l}\text { Hyperbaric oxygen therapy increases plasma } \\
\text { antioxidant defenses and may contribute to } \\
\text { activating healing resolution, angiogenesis, and } \\
\text { regulation of vascular tone by increasing the } \\
\text { release of vascular endothelial growth factor and } \\
\text { interleukin-6. }\end{array}$ \\
\hline $\begin{array}{l}\text { Chronopoulos, } \\
\quad 2015\end{array}$ & Retrospective study & $\begin{array}{l}\text { Investigate the factors that are linked to the severity of } \\
\text { mandibular osteoradionecrosis. }\end{array}$ & $\begin{array}{l}\text { The mentioned factors are predictive of the } \\
\text { severity of mandibular osteoradionecrosis and can } \\
\text { guide its prophylaxis and management. }\end{array}$ \\
\hline Grassmann, 2015 & In vivo study & $\begin{array}{l}\text { To evaluate the influence of hyperbaric oxygen therapy } \\
\text { on angiogenesis, autologous bone graft integration, and } \\
\text { bone neoformation in diaphyseal weight-bearing bone } \\
\text { defects in a rabbit model. }\end{array}$ & $\begin{array}{l}\text { The addition of hyperbaric therapy to autologous } \\
\text { bone grafts leads to significantly improved bone } \\
\text { regeneration. The observed increase in } \\
\text { angiogenesis may play a crucial role for the results } \\
\text { of the study. }\end{array}$ \\
\hline Skeik, 2015 & Retrospective study & $\begin{array}{l}\text { To present the results of treatment with hyperbaric } \\
\text { oxygen therapy in patients treated for a comprehensive } \\
\text { list of indications, including several coexisting } \\
\text { indications, at our center. }\end{array}$ & $\begin{array}{l}\text { This study provided a comprehensive survey of the } \\
\text { effectiveness of oxygen therapy for the } \\
\text { aforementioned indications in our center and } \\
\text { discussed the results of relevant articles based on } \\
\text { the literature. }\end{array}$ \\
\hline Sunkari, 2015 & In vitro study & $\begin{array}{l}\text { Investigate the influence of hyperbaric oxygen therapy } \\
\text { on HIF-1, which is a central regulator of SDF-1 and is } \\
\text { negatively regulated in diabetic wounds. }\end{array}$ & $\begin{array}{l}\text { Hyperbaric oxygen therapy stabilizes and activates } \\
\text { HIF-1, which contributes to increased cell } \\
\text { proliferation. In diabetic animals, local transfer of } \\
\text { active HIF further enhances the effects of oxygen } \\
\text { therapy on wound healing. }\end{array}$ \\
\hline Tahir, 2015 & Retrospective study & $\begin{array}{l}\text { To evaluate the efficacy and safety of hyperbaric } \\
\text { oxygen therapy in the treatment of chronic radiation- }\end{array}$ & $\begin{array}{l}\text { Oxygen therapy can be used effectively in a } \\
\text { variety of chronic radiation-induced tissue injuries; }\end{array}$ \\
\hline
\end{tabular}




\begin{tabular}{|c|l|l|l|}
\hline & & induced tissue injury. & $\begin{array}{l}\text { its favorable risk profile suggests that it should be } \\
\text { considered for patients with radiation-induced } \\
\text { tissue injuries. }\end{array}$ \\
\hline Yıldırım, 2014 & Experimental Study & $\begin{array}{l}\text { To investigate whether the edema, inflammation and } \\
\text { ischemia caused by trauma could be positively affected } \\
\text { by hyperbaric oxygen therapy and ozone therapy. }\end{array}$ & $\begin{array}{l}\text { We believe that hyperbaric oxygen therapy and } \\
\text { ozone therapy have beneficial effects on } \\
\text { biochemical and histopathological findings. }\end{array}$ \\
\hline Gupta, 2013 & Retrospective study & $\begin{array}{l}\text { To determine the effectiveness of hyperbaric oxygen } \\
\text { therapy in the management of radiation-induced } \\
\text { mandibular osteoradionecrosis. }\end{array}$ & $\begin{array}{l}\text { Our clinical experience supports the effectiveness } \\
\text { of treatment with hyperbaric oxygen therapy for } \\
\text { radiation-induced mandibular osteoradionecrosis. }\end{array}$ \\
\hline Gasier, 2013 & $\begin{array}{l}\text { Randomized } \\
\text { Clinical Trial }\end{array}$ & $\begin{array}{l}\text { Determine the effects of inspired oxygen partial } \\
\text { pressure (PiO2) on lipid peroxidation, antioxidant } \\
\text { enzyme activity, and nitric oxide (NO) production. }\end{array}$ & $\begin{array}{l}\text { Hyperoxic exposures of two hours at 1-2 atm abs } \\
\text { O2 results in mixed oxidant-antioxidant response } \\
\text { and unchanged NO production. Furthermore, there } \\
\text { does not appear to be a strong dose-dependent } \\
\text { systemic oxidative stress response in these } \\
\text { hyperoxic exposures. }\end{array}$ \\
\hline Camporesi, 2010 & Randomized \\
Clinical Trial & We evaluated hyperbaric oxygen (OHB) therapy in a a \\
cohort of patients with femoral head necrosis (FHN). & $\begin{array}{l}\text { This study demonstrates a positive therapeutic } \\
\text { outcome obtained with hyperbaric oxygen therapy } \\
\text { at mid-term follow-up, where this therapy has a } \\
\text { potential role in the treatment of avascular } \\
\text { necrosis. }\end{array}$ \\
\hline
\end{tabular}

Source: Page et al. (2021).

\section{Discussion}

Osteoradionecrosis is a condition with great potential for bone destruction, and therefore, many methods for treatment have been vehemently studied. Robert Marx (1983) was one of the first to highlight the role of hyperbaric medicine as a therapy against necrosis, where, from his research, the author pointed out that mandibular osteoradionecrosis is caused by hypoxia, as well as, due to hypocellular and hypovascular changes in irradiated tissues after radiotherapy. Therefore, Marx proposed the use of hyperbaric oxygen in a protocol, as a therapeutic intervention for cancer patients who need treatment for necrosis, thus, with the positive outcome of the research, hyperbaric therapy has been widely researched and recognized for its safety and efficacy (Rendina, 2018).

Although the mechanism of action of hyperbaric oxygen therapy is not fully understood, it is known that the physiochemistry that drives the action is a result of two factors: $100 \%$ inspired oxygen and exposure to high atmospheric pressure. In this way, oxygen therapy can increase the number of molecules that diffuse from the alveoli into the capillaries of the lungs, resulting in a high level of dissolved oxygen in the plasma, which will be transported and distributed to all surrounding body tissues (Bosco et al., 2018).

Wound healing is a complex and tightly structured process that requires a well-orchestrated interaction of molecular and cellular events, in which it is divided into several stages, among them: hemostasis, inflammation, re-epithelialization, and tissue remodeling. The activation of the immune system is also part of this stage, acting directly to remove dead cells and matrix debris from the damaged tissue (Baiula et al., 2020).

Thus, oxygen when present in larger quantities in the body, can also act in the healing process, presenting the ability to oxygenate regions where hypoxia and hypoperfusion occurred, assisting in tissue healing and healing of necrotic regions, as well as it can regulate the inflammatory response and mobilize bone marrow stem cells to promote neovascularization through angiogenesis. In contrast, low tissue oxygenation may contribute to delayed local healing, minimizing bone repair and necrosis healing (Gupta, et al., 2013; Sureda et al., 2016).

Adding further, the methodology of this therapy could be observed by Gavriel et al. (2017), where patients who suffered radiation-induced injuries to the jawbone were treated. Hyperbaric oxygen was employed using a multi-place chamber, in which a process consisting of three phases was established: compression, oxygen breathing, and decompression. The compression and decompression were performed with room air at a rate of 0.1 absolute atmospheric pressure per minute, while during the breathing phase, $100 \%$ oxygen was breathed at a pressure of 2 atmospheres absolute for 90 minutes, in which patients wore a face mask to obtain a better therapeutic effect. The study observed clinical improvement in 17 of the 20 
patients, showing fewer pain symptoms and no bone exposure after treatment.

However, this therapy is not totally innocuous and has significant issues for the patient, among them, the limitation of its access, and with that, the cost for oxygen therapy is very high. Furthermore, there are side effects presented in some patients, such as middle ear barotrauma due to the difference in ambient pressure, temporary worsening of myopia, and it is not indicated for patients who have claustrophobia, chronic obstructive pulmonary disease, or chronic heart failure (Generaal et al., 2020).

These complications were also analyzed in a retrospective study by Tahir et al. (2015), where of 189 patients, 29 had complications. Ear barotrauma was the most common side effect, present in 20 patients (10.6\%). Of these, nine patients had grade 1, ten patients had grade 2, and one patient had grade 3 ear barotrauma, however this effect was reversible and none of the patients had permanent ear toxicity, eight patients (4.2\%) had reversible myopia; one of these patients (0.5\%) also had toothache. And one patient $(0.5 \%)$ suffered a myocardial infarction during hyperbaric oxygen therapy.

Corroborating previous studies, another relevant effect cited by Gasier \& Fothergill (2013), resulting from frequent exposure to hyperbaric oxygen, is oxidative stress, caused by the production of oxygen-derived free radicals (superoxide anion, hydrogen peroxide, nitric oxide, among others). Oxidative stress is a natural physiological process, which generates an increase in enzymatic antioxidant defenses; however, its large-scale production can be harmful to patients submitted to gas inhalation, and may cause pulmonary tissue toxicity and lead to cell apoptosis. These findings highlight the significant side effects presented during hyperbaric oxygen therapy.

The results of this review present as a contribution to the clinical practice of dentistry, the knowledge about hyperbaric therapy in the treatment of osteoradionecrosis, its main advantages, and benefits, as well as highlighting the disadvantages found and its potential effects. Moreover, it awakens dental surgeons and other health professionals who assist this population, to develop further scientific studies on the use of hyperbaric oxygen in various therapeutic purposes.

A limitation of this study is that, although a broad and highly sensitive search was used, other eligible studies may not have been included because they were not indexed in the databases selected for this review. There are no specific and current national publications on the use of hyperbaric oxygen therapy in the treatment of osteoradionecrosis of the jaws in patients with head and neck cancer, which limits the analysis of this therapy in Brazil.

\section{Conclusion}

In this sense, we realize the negative impact that osteoradionecrosis has on cancer patients, being a potentially debilitating condition with great capacity for bone destruction. Thus, from the literature, it is observed how hyperbaric therapy can act in the treatment of necrosis caused by oncotherapy in patients with head and neck cancer, this fact is due to its numerous effects on oxidative metabolism, able to assist tissue repair of radiation-induced damage, promote tissue oxygenation, neovascularization and contributes to the eradication of bacteria present in damaged tissues.

On the other hand, it is necessary to correctly evaluate the indication of the treatment, because the therapy has relevant adverse effects that deserve attention, such as tissue intoxication caused by the constant inhalation of hyperbaric oxygen, as well as, since it is not such a common therapy, it has high costs and difficulty of access for the patient. In this way, more studies are needed that address the theme, exploring better its use in the dental clinic.

\section{References}

André-Lévigne, D., Modarressi, A., Pignel, R., Bochaton-Piallat, M. L., \& Pittet-Cuénod, B. (2016). Hyperbaric oxygen therapy promotes wound repair in ischemic and hyperglycemic conditions, increasing tissue perfusion and collagen deposition. Wound Repair and Regeneration, 24(6), 954-965. 
Baiula, M., Greco, R., Ferrazzano, L., Caligiana, A., Hoxha, K., Bandini, D., \& Tolomelli, A. (2020). Integrin-mediated adhesive properties of neutrophils are reduced by hyperbaric oxygen therapy in patients with chronic non-healing wound. Plos one, 15(8), e0237746.

Bosco, G., Vezzani, G., Mrakic Sposta, S., Rizzato, A., Enten, G., Abou-Samra, A., \& Camporesi, E. (2018). Hyperbaric oxygen therapy ameliorates osteonecrosis in patients by modulating inflammation and oxidative stress. Journal of enzyme inhibition and medicinal chemistry, 33(1), 1501-1505.

Camporesi, E. M., Vezzani, G., Bosco, G., Mangar, D., \& Bernasek, T. L. (2010). Hyperbaric oxygen therapy in femoral head necrosis. The Journal of arthroplasty, 25(6), 118-123.

Chronopoulos, A., Zarra, T., Tröltzsch, M., Mahaini, S., Ehrenfeld, M., \& Otto, S. (2015). Osteoradionecrosis of the mandible: a ten year single-center retrospective study. Journal of Cranio-Maxillofacial Surgery, 43(6), 837-846.

Dieleman, F. J., Phan, T. T. T., van den Hoogen, F. J. A., Kaanders, J. H., \& Merkx, M. A. (2017). The efficacy of hyperbaric oxygen therapy related to the clinical stage of osteoradionecrosis of the mandible. International journal of oral and maxillofacial surgery, 46(4), 428-433.

Gasier, H. G., \& Fothergill, D. M. (2013). Oxidative stress, antioxidant defenses and nitric oxide production following hyperoxic exposures. Undersea Hyperb Med, 40(2), 125-34.

Gavriel, H., Eviatar, E., \& Abu-Eta, R. (2017). Hyperbaric oxygen therapy for maxillary bone radiation-induced injury: A 15-year single-center experience. Head \& neck, 39(2), 275-278.

Generaal, J. D., Lansdorp, C. A., Boonstra, O., van Leeuwen, B. L., Vanhauten, H. A., Stevenson, M. G., \& Been, L. B. (2020). Hyperbaric oxygen therapy for radiation-induced tissue injury following sarcoma treatment: A retrospective analysis of a Dutch cohort. Plos one, 15(6), e0234419.

Grassmann, J. P., Schneppendahl, J., Hakimi, A. R., Herten, M., Betsch, M., Lögters, T. T., \& Hakimi, M. (2015). Hyperbaric oxygen therapy improves angiogenesis and bone formation in critical sized diaphyseal defects. Journal of Orthopaedic Research, 33(4), 513-520.

Gupta, P., Sahni, T., Jadhav, G. K., Manocha, S., Aggarwal, S., \& Verma, S. (2013). A retrospective study of outcomes in subjects of head and neck cancer treated with hyperbaric oxygen therapy for radiation induced osteoradionecrosis of mandible at a tertiary care centre: an Indian experience. Indian Journal of Otolaryngology and Head \& Neck Surgery, 65(1), 140-143.

Lockwood, C., Porrit, K., Munn, Z., Rittenmeyer, L., Salmond, S., Bjerrum, M., \& Stannard, D. (2017). Systematic reviews of qualitative evidence. JBI Reviewer's Manual [internet], 23-71.

Melnyk, B. M., \& Fineout-Overholt, E. (Eds.). (2011). Evidence-based practice in nursing \& healthcare: A guide to best practice. Lippincott Williams \& Wilkins.

Ouzzani, M., Hammady, H., Fedorowicz, Z., \& Elmagarmid, A. (2016). Rayyan—a web and mobile app for systematic reviews. Systematic reviews, 5(1), 110 .

Page, M. J., McKenzie, J. E., Bossuyt, P. M., Boutron, I., Hoffmann, T. C., Mulrow, C. D., \& Moher, D. (2021). The PRISMA 2020 statement: an updated guideline for reporting systematic reviews. Bmj, 372 .

Rendina, C. J. (2018). Hyperbaric oxygen therapy as an adjunct for treating an individual with poorly healing bilateral mandibular fractures suspect of developing towards osteomyelitis: A case report and clinical experience. Military medicine, 183(9-10), e667-e670.

Sandhu, S., Salous, M. H., Sankar, V., Margalit, D. N., \& Villa, A. (2020). Osteonecrosis of the jaw and dental extractions: A single-center experience. Oral Surgery, Oral Medicine, Oral Pathology and Oral Radiology, 130(5), 515-521.

Shaw, R., Butterworth, C., Tesfaye, B., Bickerstaff, M., Dodd, S., Smerdon, G., \& Silcocks, P. (2018). HOPON (Hyperbaric Oxygen for the Prevention of Osteoradionecrosis): a randomised controlled trial of hyperbaric oxygen to prevent osteoradionecrosis of the irradiated mandible: study protocol for a randomised controlled trial. Trials, 19(1), 1-10.

Skeik, N., Porten, B. R., Isaacson, E., Seong, J., Klosterman, D. L., Garberich, R. F., \& Sullivan, T. (2015). Hyperbaric oxygen treatment outcome for different indications from a single center. Annals of vascular surgery, 29(2), 206-214.

Souza, M. T. D., Silva, M. D. D., \& Carvalho, R. D. (2010). Revisão integrativa: o que é e como fazer. Einstein, 8, 102-106.

Sunkari, V. G., Lind, F., Botusan, I. R., Kashif, A., Liu, Z. J., Ylä-Herttuala, S., \& Catrina, S. B. (2015). Hyperbaric oxygen therapy activates hypoxiainducible factor 1 (HIF-1), which contributes to improved wound healing in diabetic mice. Wound Repair and Regeneration, 23(1), 98-103.

Sureda, A., Batle, J. M., Martorell, M., Capó, X., Tejada, S., Tur, J. A., \& Pons, A. (2016). Antioxidant response of chronic wounds to hyperbaric oxygen therapy. PLoS One, 11(9), e0163371.

Tahir, A. R. M., Westhuyzen, J., Dass, J., Collins, M. K., Webb, R., Hewitt, S., \& McKay, M. (2015). Hyperbaric oxygen therapy for chronic radiationinduced tissue injuries: Australasia's largest study. Asia-Pacific Journal of Clinical Oncology, 11(1), 68-77.

Vezzani, G., Iezzi, M., Rizzato, A., Quartesan, S., Mangar, D., Camporesi, E. M., \& Bosco, G. (2017). Effects of hyperbaric oxygen exposure on mobilization of endothelial progenitor cells in healthy volunteers. Acta Med. Mediterr, 33, 801-805.

Yıldırım, A. O., Eryılmaz, M., Kaldırım, Ü., Eyi, Y. E., Tuncer, S. K., Eroğlu, M., \& Serdar, M. (2014). Effectiveness of hyperbaric oxygen and ozone applications in tissue healing in generated soft tissue trauma model in rats: an experimental study. Turkish Journal of Trauma and Emergency Surgery, 20(3), $167-175$. 